\title{
EARLY MATHEMATICS LEARNING IN READING AND WRITING NUMERALS: LEARNING THROUGH "WHAT ARE THE NUMBERS?" A PICTURE BOOK MADE UP OF FLORA AND FAUNA IN BORNEO
}

\author{
Connie Cassy Ompok ${ }^{1}$, Ling Mei Teng ${ }^{2}$, Vincent Pang ${ }^{3}$, Ho Chong Mun ${ }^{4}$, \\ Anna Christina Abdullah ${ }^{5}$ \& Jaini Sapirai ${ }^{6}$ \\ Faculty of Psychology and Education, University Malaysia Sabah ${ }^{1346}$, \\ School of Education, Languages and Communications, Wawasan Open University ${ }^{5}$, \\ Academic Management Unit, Miri District Education Office ${ }^{2}$ \\ connieompok@ums.edu.my ${ }^{1}$, lingmeiteng@moe.gov.my ${ }^{2}$, pvincent@ums.edu.my ${ }^{3}$, \\ cmho@ums.edu.my ${ }^{4}$, annachristinaa@wou.edu.my ${ }^{5}$, jaini@ums.edu.my $^{6}$
}

\begin{abstract}
Learning through picture books is a method which is widely used in preschools to teach mathematics. However, the research findings on the benefits of using picture books in learning mathematics remain inconclusive. This study aimed to i) investigate the effects of a picture book entitled "What are the numbers?" (a picture book made up flora and fauna in Borneo) on early mathematics achievement (reading and writing numerals up to 20) and ii) to get feedback on how appropriate the use of "what are the numbers" from teachers and parents. The book consists elements of critical thinking, communication, collaboration and creative thinking. The effects were measured by comparing the change in early mathematical ability of children in reading and writing numerals up to 20 by using the Rasch measurement model. The mean of the pre-test achievement was -1.99 logits and the mean of the post-test achievement was 1.75 logits which shows a difference of 3.74 logits. The effect size of the difference between the post-test and pre-test achievement was 1.4 , which is considered large. Teachers and parents gave positive feedback on the use of the picture book. They commented that the picture book is able to attract children's attention, enhance their thinking skills and nurture creativity among children. In conclusion, the picture book based on the $4 \mathrm{C}$ approach enhanced early mathematics achievement of children.
\end{abstract}

Keywords: Learning through picture book, early mathematics achievement, reading numerals, writing numerals, Rasch analysis

\section{INTRODUCTION}

In the 21st century, it is insufficient for today's students to only acquire the traditional skills of the "3Rs" (reading, writing, and arithmetic) to be able to compete in the global society. They must also be capable communicators, creators, critical thinkers and collaborators (the "4Cs") (National Education Association, 2014). The use of picture books provide significant value in teaching and learning (Casey, Kersh and Young, 2004; Shih and Giorgis, 2004; Skoumpourdi and Mpakopoulou, 2011). Teaching with picture books is method that can be used in teaching and learning of mathematics in preschool (MOE, 2010: 47; MOE, 2016). 
"What are the numbers?" which was developed by the authors is a picture book which focuses on the 4Cs in teaching numbers (1-20). The picture book is aligned to the Malaysian National Standards-based Preschool Curriculum (Mathematics) 2016 module. One cannot learn well without thinking well, therefore critical thinking skills are important to students. Critical thinking skills lead students to develop deeper analytical abilities, higher level of concentration and enhance thought processing. Children use various types of reasoning which are appropriate to specific situations. Besides this, they are trained to synthesize and make connections between information and justify arguments. For example, children learn to read and write the numbers through natural image pictures. They have to connect the shapes of the numbers from their prior knowledge and justify arguments on the numbers that they associate with in the pictures.

In addition to the above, "What are the numbers?" trains children to articulate thoughts and ideas effectively using oral, written and non-verbal communication skills. Children write the numbers they see in the pictures in the air and read the numbers out loud. Children collaborate with their peers in the process of reading numbers form the pictures. Children who are creative can elaborate, refine, analyze and evaluate original ideas to improve and maximize creative efforts. In "What are the numbers?", the numbers are hidden in the pictures and children need to imagine creatively to read and write them. The more creative the children, the more numbers the children can read and write from each picture.

The pictures used in the book are made up of both flora and fauna found in Borneo, which are familiar to the local children. The numbers are superimposed and seemingly "hidden" in the images of flora and fauna. This study aimed i) to investigate the effects of a picture book entitled "What are the numbers?" (a picture book made up flora and fauna in Borneo) on early mathematics achievement (reading and writing numerals up to 20) and ii) to get feedback on how appropriate the use of "what are the numbers" from teachers and parents.

\section{Methodology}

\section{Subjects}

The sample consisted of 195 P1 (first year in preschool) children involved in learning through the picture book who were enrolled in the intervention programme for 23 days. Five teachers and two parents volunteers took part of this study.

\section{Instrument}

The test "Ujian Pencapaian Awal Matematik (Early Mathematics Achievement Test)" (UPAM) was used as the measurement instrument. UPAM was adapted from Ginsburg and Baroody (2003) based on the Malaysian National Standards-based Preschool Curriculum, 2010. The test consists of 40 items. The scale used in the test is a dichotomous scale $(0=$ wrong, $1=$ correct $)$. For the purpose of this article, four items (reading and writing numerals up to 20) were used to measure the relevant early mathematics ability of the children.

\section{Picture book ("What are the numbers?")}

"What are the numbers?" used in the intervention was self-developed by the researchers. This book, which was aimed to help the children in reading and writing numerals up to 20, was specifically designed based on flora and fauna of Borneo. The book was used with the 4C learning 
module which features critical thinking, communication, creativity and collaboration in the approach.

\section{Procedure}

Based on single group quasi-experimental design, the change in early mathematics ability of the preschool children in reading and writing numerals up to 20 was analysed by using the Rasch measurement model. The preschool children sat for a pre-test (time 1), followed by 20 days of intervention program (learning through picture book to read and write numerals from 1 to 20) and ended with a post-test (time 2) which was of equivalent standard. Feedback on how appropriate the use of "what are the numbers" from teachers and parents were achieved by using qualitative approach.

The stack analysis was done by preparing a data file that contained two rows of data per student; one for the pre-test responses and another for the post-test responses (Herrmann-abell, Flanagan \& Roseman, 2013). By stacking the data, a researcher is able to see who has changed after the intervention (Wright, 2003). The person samples must be measured on the same "ruler" so that Time1-to-Time 2 changes can be computed (Wright, 2003). Item measures in Time 2 were anchored because that is when success or failure decisions are made (Wright, 2003). Teachers and parents were invited to give comments on the application of the 4C's picture book in teaching numbers.

\section{Findings and Discussion Properties of Instrument}

The positive item polarity ranged from 0.69 to 0.77 shows that the four items are measuring the construct in the same direction (Linacre, 2005). The infit and outfit mean square values for all of the items were within the acceptable range of 0.5 to 1.5 , (Linacre and Wright, 2012). The item separation value of more than 3.0 and item reliability of more than 0.9 imply that the person sample was enough to confirm the item difficulty hierarchy, which is the construct validity of the instrument (Linacre \& Wright, 2012). The person separation of less than 2.0 and person reliability of less than 0.8 with a relevant person sample implied that the instrument was not sensitive enough to distinguish between high and low performers (Linacre and Wright, 2012; Sherron,

2000). To address this issue, more items are usually suggested. However, as this is only one part (4 items) of the UPAM test which consists of 40 items, no extra item was added to measure reading and writing numerals. The variance of raw observations between $40 \%$ and $50 \%$ are typical values (Linacre, 2003). The Eigen value of less than 5.0 indicates that the test is probably unidimensional (Linacre, 2005). In conclusion, the instrument showed good Rasch properties. 
Table 1. Summary of Rasch Analysis Properties of UPAM

\begin{tabular}{|c|c|}
\hline Criteria & Statistical Information \\
\hline Item polarity & PTMEA Corr. $>0$ (positive values) \\
\hline Item fit & Infit and outfit mean square 0.98 to 1.38 \\
\hline Item separation & 7.31 \\
\hline Item reliability & 0.98 \\
\hline Person separation & 1.02 \\
\hline Person reliability & 0.51 \\
\hline $\begin{array}{l}\text { Principal Component Analysis of } \\
\text { residuals (PCAR) }\end{array}$ & $\begin{array}{l}\text { Raw variance explained by measures }=42.5 \% \\
\text { Unexplained variance in } 1 \text { st contrast }=\text { Eigen value }\end{array}$ \\
\hline
\end{tabular}

\section{Stacked Analysis with anchor for student learning through Picture book}

The results show generally inconsistent changes in early mathematical ability of children in reading and writing numerals up to 20 after intervention (learn through picture book). Not all students show increments in early mathematical ability in reading and writing numerals up to 20 . The mean of pretest achievement was -1.99 logits and the mean of post-test achievement was 1.75 logits which shows a difference of 3.74 logits. The effect size of the difference between the post-test and pretest achievement was 1.4, which is considered large (Cohen, 1988). Therefore, from the analysis, on average, most students improved their ability to read and write within the number range. 147 out of $195(75.4 \%)$ children show increments in early mathematical ability in reading and writing numerals up to 20. There were only six children (A035, A057, A032, A029, A030 and A031) out of 195 who showed decreases in reading and writing ability while that of 42 children remain unchanged after the intervention.

This study shows that the picture book facilitated the majority of the children in writing and reading numbers. Simple learning outcomes such as writing numerals and reading numerals can be achieved by learning through a picture book. This could be due to the ability of picture books in supporting memorisation, motivation, and interest of children; while reducing fear and facilitating a comfortable environment and positive relationships between teachers and pupils (Zazkis \& Liljedahl, 2009). Previous studies have shown that picture books facilitate and encourage children in naming shapes (Preissler \& Carey, 2004; Skoumpourdi \& Mpakopoulou,

2011).

The findings on the picture book supporting learning of writing and reading numbers was reinforced by feedback from the teachers and parents.

"Buku ini membantu murid-murid dalam mengenali nombor... Ada murid yang lebih kreatif dapat membaca lebih daripada satu nombor dalam satu gambar (This book helps pupils in recognising numbers. More creative pupils can read more than one number in a picture)" [Tan, a teacher]. 
“...Anak saya tunjuk nombor dalam gambar kepada saya. Dia beritahu saya nombor tersebut adalah satu... Lepas itu, saya minta dia tunjuk...Dia pun tunjuk dengan jari dia ke arah seruling tu dan menunjukkan bentuk nombor satu... sama juga nombor lain seperti lima, dia boleh ikut tu bentuk badan ular tu dan tunjukkan bentuk nombor lima... Gambar dalam buku ini boleh membantu anak saya lebih ingat bentuk nombor. (My child showed the numbers in the picture to me. She told me the number is one... After that, I asked her to point ... She pointed her finger at the flute and showed me the number one... the same with other numbers such as five, she could follow the shape of the snake's body and show me the shape of number five... The pictures in the book can help my child to remember the shape of the numbers.) [Kueh, a parent].

Some teachers agreed that pictures in the book help children in developing their thinking skills through imagination. They mentioned that the children have to think first before they can read and write the numbers.

“... Ia juga dapat menggalakkan murid untuk berfikir dengan berimaginasi tentang gambar yang dilihat..."(It also encourages pupils to think and imagine the pictures that they have seen.)" [Jude, a teacher].

“... Kanak-kanak juga dapat berimaginasi di samping dapat mengembangkan kemahiran berbahasa dengan lebih baik. Ilustrasi yang ditunjukkan juga tidak terikat kepada maksud tertentu sahaja tetapi ianya juga boleh diolah atau ditafsir menjadi nombor yang lain. (The book is full of pictures and colours. Children can also imagine besides developing their language skills. The illustrations are not necessarily tied to just one specific meaning but can also be reconstructed and interpreted to other numbers. )" [Zac, kindergarten supervisor].

"Buku ini memerlukan kanak-kanak berfikir kerana simbol nombor tidak ditonjolkan secara terus seperti buku-buku matematik lain. Kanak-kanak akan berfikir gambar ini seperti nombor apa ya? Kanak-kanak akan berfikir secara analitikal untuk menjustifikasikan gambar kepada bentuk nombor yang sebenar. Maksudnya kanak-kanak tidak boleh menjawab secara spontan kerana dia perlu memastikan terlebih dahulu apakah ia betul atau salah." (The book requires children to think because the symbols of numbers are not displayed clearly as in other mathematics books. Children will have to think analytically to justify why certain pictures reflect the shapes of specific numbers. This means that the children cannot answer spontaneously because they have to first make sure whether it is correct or wrong.) [Muhammad, a teacher].

One of the parents commented that the pictures in the book can develop children's creativity. "...Can train the children's creativity. Children who can read out more numbers are very creative.." [Coco, a parent]

On the other hand, one of the teachers also found that the book is able to combine the logical thinking skill and creativity. This is what she commented to the researcher,

"It is good! This is like a combination of left brain and right brain learning. Creative and logic..." [Ian: Teacher D]. 
In addition, a pre-school teacher and kindergarten supervisor commented that the book is able to attract the children.

"Buku tersebut sangat menarik perhatian murid-murid kerana pemilihan warna yang menarik dan pelbagai. (The book is able to attract the attention of pupils because of the choice of colours which are diverse and attractive.)" [Jude, a teacher].

"Buku tersebut dipenuhi dengan gambar dan warna yang memenuhi seluruh helaian. Melalui pemilihan ilustrasi juga amat menarik dan sesuai dengan perkembangan pemikiran kanak-kanak masa kini iaitu lebih focus kepada fantasi. (The illustrations are also very attractive and suitable for developing thinking skills among pupils who are also into imaginative thinking.)" [Zac, a kindergarten supervisor].

Furthermore, children can relate the pictures in the book to their surroundings, too. This was mentioned by one of the teachers,

"...Murid juga dapat mengaitkan flora dan fauna dengan bentuk atau nombor yang ada di sekeliling mereka. (Pupils can also relate the flora and fauna to the shapes or numbers that exist around them.)" [Jude, a teacher]

However, from the Rasch analysis, not all pupils in the sample showed increment in their performance after intervention. The ability of children A035, A057, A032, A029, A030 and A031 decreased after intervention. Based on the scalogram, researchers found that children A035 and A057 are high achievers because their logit measures are high (2.41). They could score very well in pre-test but were only able to answer correctly one item in the post-test. This might be due to carelessness of the children. On the other hand, children A032, A029, A030 and A031 who were low achievers, scored one item correctly in pre-test but none in post-test. The children might be guessing in the pre-test.

Table 2. The Scalogram Results of Children A035, A057, A032, A029, A030 and A031 in Time 1 and Time 2

\begin{tabular}{|c|c|c|c|c|c|}
\hline \multirow{2}{*}{ ID } & \multicolumn{2}{|c|}{$\begin{array}{l}\text { Ability in reading and } \\
\text { writing numerals }\end{array}$} & \multirow{2}{*}{ Test } & \multirow{2}{*}{$\begin{array}{l}\text { Item } 14, \text { A15, } \\
\text { A28, } 29 \\
\text { (1=correct, } \\
\text { 0=wrong) }\end{array}$} & \multirow{2}{*}{$\begin{array}{l}\text { Diagnosis } \\
\text { assumption }\end{array}$} \\
\hline & Pre-test & Post-test & & & \\
\hline \multirow{2}{*}{ A035 } & \multirow{2}{*}{2.41} & \multirow{2}{*}{-1.75} & Pre-test (Time 1) & +1110 & \multirow{2}{*}{ Careless } \\
\hline & & & Post-test (Time 2) & +0100 & \\
\hline \multirow{2}{*}{ A057 } & \multirow{2}{*}{2.41} & \multirow{2}{*}{-1.75} & Pre-test (Time 1) & +1110 & \multirow{2}{*}{ Careless } \\
\hline & & & Post-test (Time 2) & +1000 & \\
\hline \multirow{2}{*}{ A032 } & \multirow{2}{*}{-0.08} & \multirow{2}{*}{-3.45} & Pre-test (Time 1) & +1010 & \multirow{2}{*}{ Guessing in pre-test } \\
\hline & & & Post-test (Time 2) & +0000 & \\
\hline \multirow{2}{*}{ A029 } & \multirow{2}{*}{-1.75} & \multirow{2}{*}{-3.45} & Pre-test (Time 1) & +0100 & \multirow{2}{*}{ Guessing in pre-test } \\
\hline & & & Post-test (Time 2) & +0000 & \\
\hline \multirow{2}{*}{ A030 } & \multirow{2}{*}{-1.75} & \multirow{2}{*}{-3.45} & Pre-test (Time 1) & +0100 & \multirow{2}{*}{ Guessing in pre-test } \\
\hline & & & Post-test (Time 2) & +0000 & \\
\hline \multirow{2}{*}{ A031 } & \multirow{2}{*}{-1.75} & \multirow{2}{*}{-3.45} & Pre-test (Time 1) & +1000 & \multirow{2}{*}{ Guessing in pre-test } \\
\hline & & & Post-test (Time 2) & +0000 & \\
\hline
\end{tabular}




\section{CONCLUSION}

As a conclusion, learning through a picture book entitled "What are the numbers?" A picture book made up of flora and fauna in Borneo, can enhance children's learning ability in early mathematics. This is probably because the picture book is able to support memory, increase motivation and interest of children, and reduce fear towards mathematics in the early years. Some children, especially low achievers might need more time to get used to this method as the pictures used in the picture book do not show conspicuous images of numbers. Children need to think and imagine the numbers rather than just read and write the numbers. $4 \mathrm{C}$ skills should be emphasized in teaching and learning process of pre-school children. More research to be carried out for the improvement of using the picture books based nature.

\section{REFERENCES}

Casey, B.M., Kersh, J.E. and Young, J.M. (2004). Storytelling sagas: An effective medium for teaching early childhood Mathematics. Early Childhood Research Quarterly. 19:167-172.

Cohen, J. (1998). Statistical power analysis for the behavioral sciences $\left(2^{\text {nd }}\right.$ ed.). Hillsdale, NJ:Erlbaum

Ginsburg, H.P. and Baroody, A.J. (2003). Test of early Mathematics ability (3 ${ }^{\text {rd }}$ edition). Austin: PRO- ED SAGE Publications.

Herrmann-abell, C.F., Flanagan, J.C. \& Roseman, J.E. (2013). Developing and evaluating an eight grade curriculum unit that links foundational chemistry to biological growth: Using student measures to evaluate the promise of the intervention. Paper presented at NARST Annual Intervention Conference, San Cristobal (p.21). Rio GrandePuerto Rico: NARST

Kementerian Pendidikan Malaysia. ( 2010). Kurikulum Standard Prasekolah Kebangsaan. Kuala Lumpur: Bahagian Pembangunan Kurikulum.

Kementerian Pendidikan Malaysia. ( 2016). Kurikulum Standard Prasekolah Kebangsaan. KualaLumpur: Bahagian Pembangunan Kurikulum.

Linacre, J. M. (2003). Dimensionality: contrasts \& variances. Retrieved January 20, 2015, from http://www.winsteps.com/winman/principalcomponents.htm

Linacre, J. M. (2005). A users guide to WINSTEPS. Chicago. Retrieved from http://ifile.hkedcity.net/1/001/950/public/Secondary/EI0020070012/winsteps.pdf

Linacre, J. M. \& Wright, B. D. (2012). A user's guide to WINSTEPS ministeps Rasch model computer programs. Chicago: Mesa Press.

National Education Association. (2014). Preparing 21st Century Students for a Global Society: An Educator's Guide to the "Four Cs."

Preissler, M.A. and Carey, S. (2004). Do both pictures and words function as symbols for 18 and 24 month old children? Journal of Cognition and Development. 5(2):185-212.

Sherron, C. T. (2000). Psycometric Development of The Adaptive Leadership Competency Profile. University of North Texas.

Shih, J. and Giorgis, C. ( 2004). Building the Mathematics and literature connection through children's responses. Teaching Children Mathematics. 10(6):328-333.

Skoumpourdi, C. and Mpakopoulou, I. (2011). The prints: A picture book for pre-formal geometry. Early childhood Education Journal. 39:197-206. 
Van den Heuvel-Panhuizen, M., Van den Boogaard, S. and Doig, B. (2009). Picture books stimulate the learning of Mathematicss. Australia Journal of Early Childhood. 34(3), 30-39.

Wright, B.D. (2003). Rack and stack: Time 1 vs Time 2 or Pre-test vs. Post test. Rasch measurement transaction. 17(1), 905-906.

Young-Loveridge, J.M. (2004). Effects on early numeracy of a program using picture books and games. Early Childhood Research Quarterly. 19, 82-98.

Zazkis, R. and Liljedahl, P. (2009). Teaching Mathematicss as storytelling. Netherlands: Sense Publishers.

https://www.oyezbookstore.com/browse--

buy.html? mode=product $\& \sim \sim \mathrm{id}=99210126 \# ! /$ What-are-the-Numbers/p/99210126
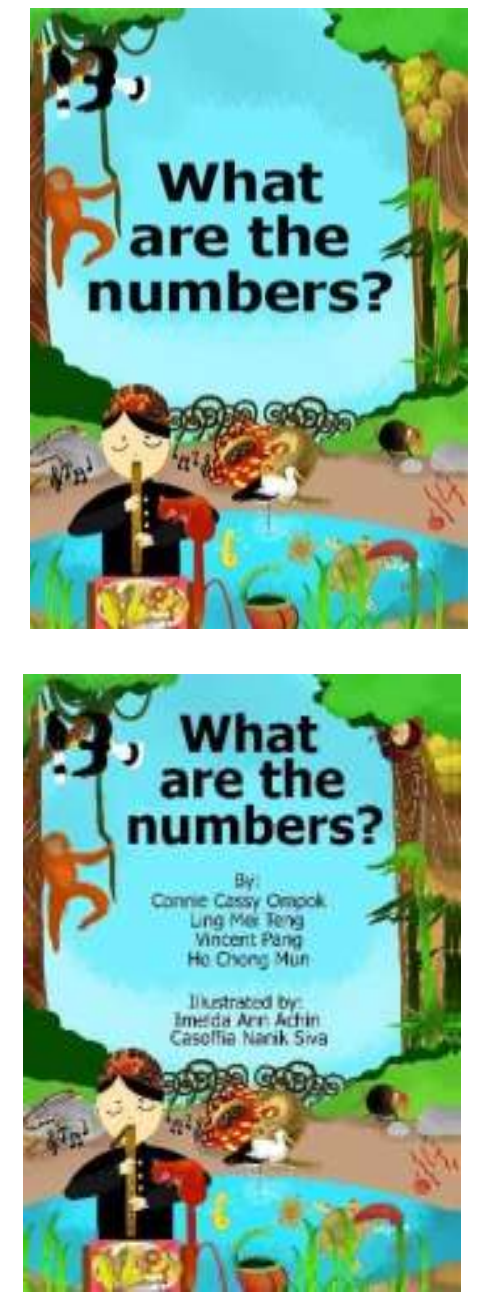